\title{
Effects of foliar nickel (Ni) application on mineral nutrition status, urease activity and physiological quality of soybean seeds
}

\author{
Jéssica Pigatto de Queiroz Barcelos ${ }^{1}$, Christian Rones Wruck de Souza Osório², Aguinaldo José \\ Freitas Leal ${ }^{3}$, Charline Zaratin Alves ${ }^{2}$, Elcio Ferreira Santos ${ }^{4}$, Heitor Pontes Gestal Reis ${ }^{1}$, André \\ Rodrigues dos Reis ${ }^{1,5^{*}}$
}

\author{
${ }^{1}$ UNESP - Universidade Estadual Paulista, Ilha Solteira, SP, Brasil \\ ${ }^{2}$ UFMS - Universidade Federal de Mato Grosso do Sul, Chapadão do Sul, MS, Brasil \\ ${ }^{3}$ UFTM - Universidade Federal do Triangulo Mineiro, Iturama, MG, Brasil \\ ${ }^{4}$ USP - Universidade de São Paulo, Piracicaba, SP, Brasil \\ ${ }^{5}$ UNESP - Universidade Estadual Paulista, Tupã, SP, Brasil
}

*Corresponding author: andrereis@tupa.unesp.br (A.R. Reis)

\begin{abstract}
Nickel (Ni) at low concentrations is an essential micronutrient for higher plants. Nickel is a cofactor of the enzyme urease and plays a critical role in the germination of seeds. This study aims to evaluate the effect of foliar Ni application on mineral nutrition status, urease activity and the physiological quality of soybean seeds. The study was conducted using different levels of Ni $(0,10,20,40$, 60,80 and $\left.100 \mathrm{~g} \mathrm{ha}^{-1}\right)$ were applied in the presence or absence $\left(0\right.$ or $75 \mathrm{~g}$ i.a. ha $\left.{ }^{-1}\right)$ of the fungicide pyraclostrobin. Leaf nitrogen concentrations showed a linear increase in response to $\mathrm{Ni}$ application irrespective of pyraclostrobin application. Foliar sulfur concentrations inversely proportional to $\mathrm{Ni}$ application in the absence of pyroclostrobin, but were proportional to Ni application when pyroclostrobin was also applied. Nickel application showed no effects on foliar concentrations of other macronutrients $\left(\mathrm{P}, \mathrm{K}^{+}, \mathrm{Ca}^{2+}\right.$, $\mathrm{Mg}^{2+}$ ). Nickel concentrations in the leaves and seeds were proportional to nickel applications levels. There was a highly significant correlation between foliar Ni concentrations in the leaves and seed Ni levels $(r=0.99)$, indicating extensive translocation of $\mathrm{Ni}$ from leaf to seed. Urease activity increased proportionally up to $20 \mathrm{~g} \mathrm{ha}^{-1}$, with peak activity between 20 and $40 \mathrm{~g} \mathrm{ha}^{-1}$ of Ni. Urease activity correlated highly with seed yield $(r=0.88)$ and pod number $(r=0.84)$. Seed germination and emergence rate increased proportionally with $\mathrm{Ni}$ application. However, when $\mathrm{Ni}$ was combined with pyraclostrobin, the germination percentage displayed a parabolic curve with an increase of germination up to $40 \mathrm{~g} \mathrm{ha}^{-1}$ of Ni. The electrical conductivity for a maximum was between 40 and $60 \mathrm{~g} \mathrm{ha}^{-1}$ of Ni. Nickel treatments had no significant effect on seedling length or seedling dry weight. Foliar application of Ni up to $20 \mathrm{~g} \mathrm{ha}^{-1}$ in the presence or absence of pyraclostrobin was beneficial to soybean plants based on seed yield, mineral nutrition status and physiological quality of soybean seeds.
\end{abstract}

Keywords: Pyraclostrobin, micronutrient, urease, physiological quality, soybean.

\section{Introduction}

One of the most important steps in soybean production is to obtain high quality seeds. However, several factors affect the quality of seeds, among them fertilizer highlighting (Sá, 1994; Kappes et al., 2008). The occurrence of micronutrient deficiencies can limit productivity, decrease seed quality, and interfere with phytosanitary matters (Kappes et al., 2008).

Nickel was originally classified as non-essential and toxic to plants (Malavolta and Moraes, 2007). However, its essentiality was confirmed by direct demonstration of its role as a cofactor for the enzyme urease (EC 3.5.1.5., urea amidohydrolase) (Dixon et al., 1975), and experimental correlation of $\mathrm{Ni}$ with seed germination in soybeans (Eskew et al., 1983) and cowpeas (Vigna unguiculata) (Eskew et al., 1984). Urea is produced in plant tissues as a product of arginine catabolism, which is particularly important in the nitrogen remobilization process during seed germination and senescence, and is present in all higher plants (Walker et al., 1985; Witte, 2011; Kutman et al., 2013a). Soybean plants have two additional pathways of urea biosynthesis: one is purine catabolism, leading to formation of ureides (allantoin and allantoic acid), which comprise the main form of reserve for translocation of nitrogen from the roots to shoots (a characteristic trait of legumes); from the other involves the amino acid, canavanine, found only in cowpea and soybean plants which is involved in glutamine synthesis biosynthesis (Walker et al., 1985; Zonia et al., 1995). In higher plants, urea is recycled only by the action of urease (Polacco et al., 2013), which catalyzes the hydrolysis of urea into ammonia and carbon dioxide (Dixon et al., 1975). Urease has two Ni ions in the active site (Ciurli, 2001). Foliar applications of $\mathrm{Ni}$ have been demonstrated to increase foliar Ni concentration and foliar urease activity (Ojeda-Barrios et al., 2016). Plants growing in $\mathrm{Ni}$ deprivation conditions produce seeds with low germination rates and reduced growth of seedlings. This situation is reversed by the addition of low concentrations of $\mathrm{Ni}$ to liquid fertilizers (Eskew et al., 1983; Brown et al., 1987). Other experiments, however, have shown that the Ni concentration in seeds has a greater influence on germination 
and seedling vigor. In addition, foliar application of $\mathrm{Ni}$ can prevent toxic symptoms caused by urea accumulation in leaf tissue, and glyphosate drift symptoms (Eskew et al., 1984; Kutman et al., 2013b; Kutman et al., 2014). Urease inhibitors prevent the germination of seeds, and this effect is reversed with the addition of $\mathrm{NH}_{4} \mathrm{NO}_{3}$ and amino acids (Zonia et al., 1995). In this sense, $\mathrm{Ni}$ availability to soybean plants could $\mathrm{Ni}$ levels in the seeds by promoting urease activity and contribute to production of seeds with better physiological quality (Lavres et al., 2016).

Thus, optimal concentrations of micronutrients in seeds can enhance the growth and productivity of crops, particularly in nutrient-poor soils (Kutman et al., 2014). In addition, the foliar applications of $\mathrm{Ni}$ at low concentrations can play various roles in increasing resistance to fungal disease (Reis et al., 2014; Langenbach et al., 2016). Another important aspect of seed production refers to the plant's vitality, and the physiological quality of seeds. In order to improve both it is common to apply foliar fungicides for fungal soybean disease control (Godoy et al., 2016).

It is known that some types of fungicides have physiological effects on plants. The application of pyraclostrobin to soybean plants can promote an increase in the photosynthetic rate and the foliar nitrate reductase activity, and a decrease in the respiratory rate (Fagan, 2010; Carrijo, 2014). In this study, we hypothesize that the application of foliar Ni combined with pyraclostrobin during the anthesis stage, could enhance the urease activity and contribute to improved physiological quality of soybean seeds and yields. This is the first report in the literature showing the synergistic effect of $\mathrm{Ni}$ combined with pyraclostrobin on physiological quality of soybean seeds. This study aims to evaluate the interactions between mineral nutrition status, urease activity and physiological quality of soybean seeds in response to foliar $\mathrm{Ni}$ application in the presence or absence of pyraclostrobin.

\section{Results and Discussion}

\section{Mineral nutrition status of soybean leaves and grains}

Leaf nitrogen concentrations in soybean plants showed a proportional linear increase in response to foliar $\mathrm{Ni}$ application regardless of pyraclostrobin status (Fig. 1a). Nickel plus pyraclostrobin exhibited an additive effect on leaf nitrogen concentrations (Fig. 1a). Similar results were obtained for foliar Ni application in tomato (Tan et al., 2000) and soybean plants (Kutman et al., 2014). Increases in foliar nitrogen concentrations in banana plants treated with pyraclostrobin were also observed by Lima et al. (2012). The mechanism of action of pyraclostrobin is to increase the nitrate reductase activity, which improves the nitrogen assimilation in plants (Rodrigues, 2009; Fagan, 2010; Carrijo, 2014).

Foliar sulfur concentrations linearly decreased with $\mathrm{Ni}$ foliar spray application. However, sulfur concentrations linearly increased when the foliar $\mathrm{Ni}$ application was combined with pyraclostrobin (Fig. 1f). In general, the literature points to sulfur interactions with other nutrients such as iron, molybdenum, selenium and zinc (KabataPendias and Pendias, 2011). There is a lack of information in the literature regarding the interaction between $\mathrm{Ni}$ and sulfur. Lavres et al. (2016) observed an increase in foliar sulfur concentrations in soybean plants by applying Ni through seed priming technique. On the other hand, Rodak (2014) observed no significant effect of $\mathrm{Ni}$ application via soil on soybean foliar sulfur concentrations. No previous studies regarding the effect of pyraclostrobin on foliar sulfur concentration in soybean plants and its interaction with $\mathrm{Ni}$ have been done. Further studies are needed in order to elucidate the interactions between $\mathrm{Ni}$, pyraclostrobin and sulfur metabolism in higher plants.

According to Malavolta and Moraes (2007), nitrogen and sulfur may interact synergistically. The three-dimensional structure of nitrate reductase contains a sulphite oxidase (Campbell, 1999), and the molecule had sulfur contanining amino acids. Some studies have found decreased nitrate reductase activity under sulfur-limiting conditions (Thomas et al., 2000; Prosser et al., 2001).

Studies have shown that $\mathrm{Ni}$ has no effect on nitrate reductase activity in sugar beets (Kevresan et al., 1998) and soybeans (Rodak, 2014), whereas pyraclostrobin increases nitrate reductase activity, leading to an increase in foliar nitrogen concentration in plants (Rodrigues, 2009; Fagan, 2010). The increase in foliar sulfur concentrations may occur through the indirect influence of $\mathrm{Ni}$ on foliar nitrogens concentration and of pyraclostrobin on nitrate reductase enzyme. However, the effects of Ni concentration may vary between plants of the same genus, or even between different cultivars of the same species (Barsukova and Gamzikova, 1999; Seregin Kozhevnikova, 2006).

Foliar $\mathrm{Ni}$ application showed no effect on foliar concentrations of other macronutrients such as phosphorus, potassium, calcium and magnesium (Figs. 1b, 1c, 1d, 1e). Foliar boron concentrations increased linearly with increased $\mathrm{Ni}$ application. Whereas when $\mathrm{Ni}$ is combined with pyroclostrobin, there was a significant decrease in boron levels at high $\mathrm{Ni}$ concentrations (Fig. 2a). Franco (2015) also observed increases in foliar boron concentrations in soybean plants in response to Ni levels. Rodak (2014) reported boron levels to be inversely proportional to Ni levels in both leaves and seeds. There is little in the literature regarding the interaction between $\mathrm{Ni}$ and boron and what is available often reports contradictory observations.

In the absence of pyroclostrobin, foliar copper concentrations showed a parabolic response to $\mathrm{Ni}$ application with peak concentrations at about $40 \mathrm{~g} \mathrm{ha}^{-1}$ whereas when combined with pyroclostrobin, the initial copper concentration started higher then decreased with increasing $\mathrm{Ni}$ concentrations. (Fig. 2b). The antagonistic relationship between $\mathrm{Cu}$ and $\mathrm{Ni}$ has been show in soybeans (Cataldo et al., 1978) and barley (Korner et al., 1987). In this study, the highest copper concentrations in soybean leaves was observed between 40 and $60 \mathrm{~g} \mathrm{ha}^{-1}$ of foliar $\mathrm{Ni}$ application. Some studies suggest that $\mathrm{Ni}$ exerts synergistic effects on copper absorption (Küpper and Andresen, 2016). This synergistic effect was also observed in Alyssum inflatum, a hyperaccumulator species of $\mathrm{Ni}$ (Ghasemi et al., 2009; Ghasemi et al., 2015).

In the absence of pyroclostrobin, foliar iron concentrations demonstrated a modest parabolic response with peak iron concentrations obtained at $40 \mathrm{~g} \mathrm{ha}^{-1}$. However, when combined with pyroclostrobin, iron concentrations demonstrated an inverted parabolic curve with the highest concentrations occurring at $10 \mathrm{~g} \mathrm{ha}^{-1}$ (Fig. 2c). Similar results related to increases in iron concentration in soybean leaves were observed by Rodak (2014) and (Franco, 2015). This happens because tropical soils have iron availability for plants (Kämpf et al., 2012). In plants grown in nutrient solution Rahman et al. (2005) found lower absorption of iron, which causes the two cations to compete with each other for absorption sites (Nishida, 2012). These authors found that the accumulation of $\mathrm{Ni}$ induces the expression of IRT1, an iron 1 transport regulator gene and member of the ZIP family, causing more $\mathrm{Ni}$ to be absorbed by that carrier. 
Table 1. Relationship among $\mathrm{N}$ - nitrogen $\left(\mathrm{g} \mathrm{kg}^{-1}\right)$; Mn - manganese $\left(\mathrm{mg} \mathrm{kg}^{-1}\right)$; $\mathrm{Zn}$ - zinc $\left(\mathrm{mg} \mathrm{kg}^{-1}\right)$; Ni - nickel $\left(\mathrm{mg} \mathrm{kg}^{-1}\right)$; RL - root lenght ( $\mathrm{cm}^{-1}$; $\mathrm{SDW}$ - shoot dry weigh $(\mathrm{g})$; RDW - root dry weight $(\mathrm{g})$; SPAD - chlorophyll index; urease $\left(\mu \mathrm{mol} \mathrm{N}-\mathrm{NH}_{4}{ }^{+} \mathrm{g}^{-1} \mathrm{FW} \mathrm{h}{ }^{-1}\right)$; yield $\left(\mathrm{kg} \mathrm{ha}^{-1}\right)$, and pod.

\begin{tabular}{|c|c|c|c|c|c|c|c|c|c|c|c|c|c|}
\hline & $\mathrm{N}$ & $\mathrm{Mn}$ & $\mathrm{Zn}$ & Ni-leaf & RL & SDW & RDW & SPAD & urease & yield & pod & grains & Ni-grain \\
\hline $\mathrm{N}$ & 1 & & & & & & & & & & & & \\
\hline $\mathrm{Mn}$ & $n s$ & 1 & & & & & & & & & & & \\
\hline $\mathrm{Zn}$ & $n s$ & $n s$ & 1 & & & & & & & & & & \\
\hline Ni-leaf & $0.96^{*}$ & $n s$ & $-0.86^{*}$ & 1 & & & & & & & & & \\
\hline RL & $n s$ & $n s$ & $n s$ & $n s$ & 1 & & & & & & & & \\
\hline SDW & $n s$ & $n s$ & $n s$ & $n s$ & $n s$ & 1 & & & & & & & \\
\hline RDW & $n s$ & $n s$ & $n s$ & $n s$ & $n s$ & $0.93^{*}$ & 1 & & & & & & \\
\hline SPAD & $0.83^{*}$ & ns & $-0.90^{*}$ & $0.92^{*}$ & $n s$ & $n s$ & ns & 1 & & & & & \\
\hline urease & $n s$ & $n s$ & $n s$ & $0.81^{*}$ & $n s$ & $n s$ & $n s$ & $n s$ & 1 & & & & \\
\hline yield & $n s$ & $n s$ & $n s$ & $n s$ & $n s$ & ns & $n s$ & $n s$ & $0.64^{*}$ & 1 & & & \\
\hline pod & $n s$ & $n s$ & $n s$ & $n s$ & $0.88^{*}$ & $n s$ & $n s$ & $n s$ & $0.88^{*}$ & $0.84^{*}$ & 1 & & \\
\hline grains & $n s$ & $n s$ & $n s$ & $n s$ & $-0.89^{*}$ & $n s$ & $n s$ & $n s$ & $n s$ & $n s$ & $-0.83^{*}$ & 1 & \\
\hline Ni-grain & $0.98^{*}$ & $n s$ & $-0.79^{*}$ & $0.99^{*}$ & $n s$ & $n s$ & $n s$ & $n s$ & $n s$ & $n s$ & $n s$ & ns & 1 \\
\hline
\end{tabular}

ns - Not significant: is: Significant at $1 \%,(\mathrm{p} \leq 0,0001)$

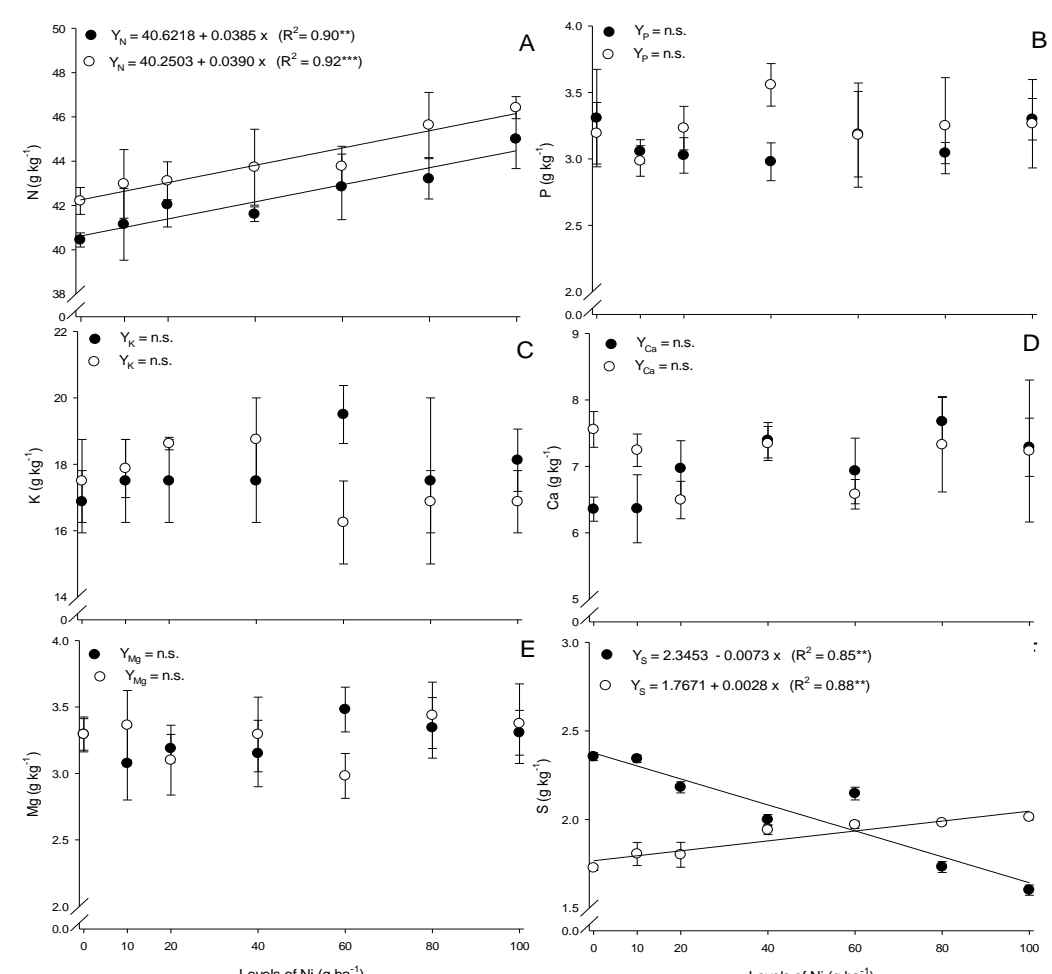

Fig 1. Nitrogen (N) [A], phosphorus $(\mathrm{P})[\mathrm{B}]$, potassium $(\mathrm{K})[\mathrm{C}]$, calcium $(\mathrm{Ca})[\mathrm{D}]$, magnesium $(\mathrm{Mg})[\mathrm{E}]$, and sulfur concentration $(\mathrm{S})[\mathrm{F}]$ in soybean leaves in response to Ni application with or without pyraclostrobin. Open circles: $\mathrm{Ni}+$ pyraclostrobin; dark circles: $\mathrm{Ni}$ only. The error bars indicate the standard deviation of four replicates $(n=4)$. 


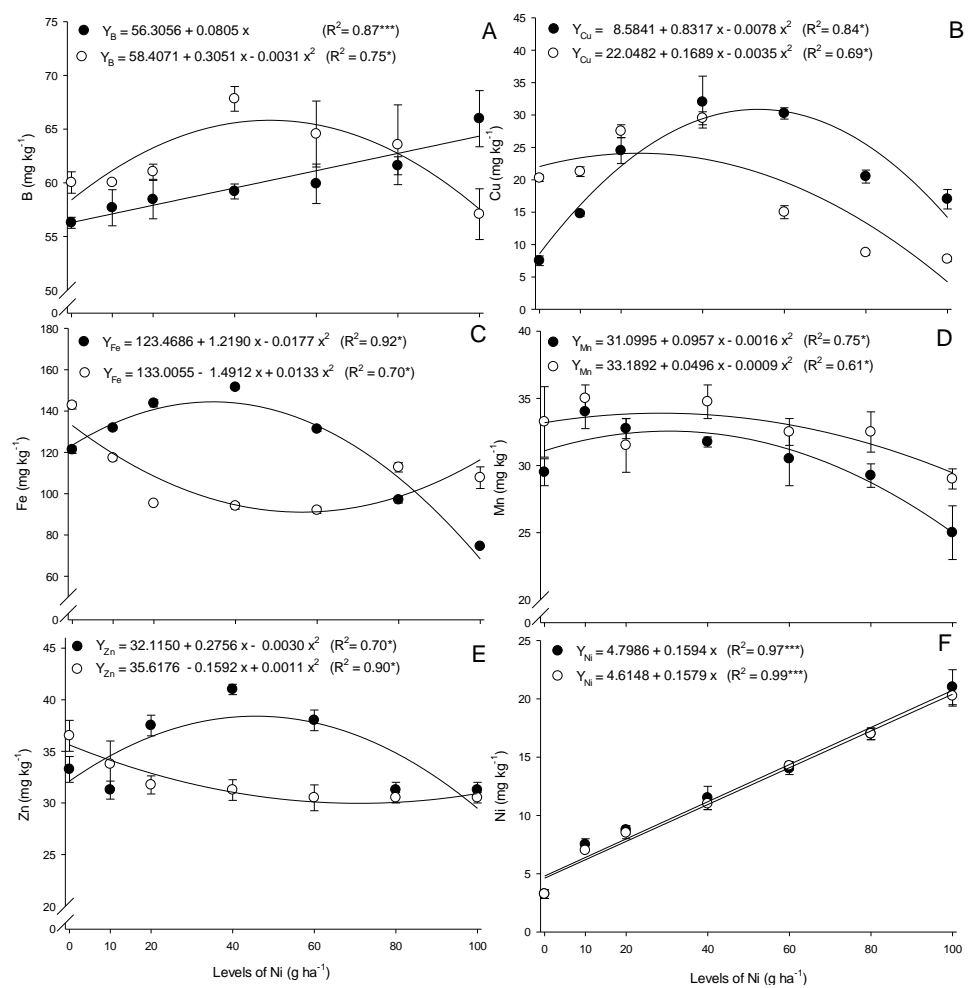

Fig 2. Boron (B) $[A]$, copper $(\mathrm{Cu})[\mathrm{B}]$, iron $(\mathrm{Fe})[\mathrm{C}]$, manganese $(\mathrm{Mn})[\mathrm{D}]$, zinc $(\mathrm{Zn})[\mathrm{E}]$ and nickel concentration $(\mathrm{Ni})[\mathrm{F}]$ in soybean leaves in response to $\mathrm{Ni}$ application with or without pyroclostrobin. Open circles: $\mathrm{Ni}+$ pyraclostrobin; dark circles: $\mathrm{Ni}$ only. The error bars indicate the standard deviation of four replicates $(n=4)$.
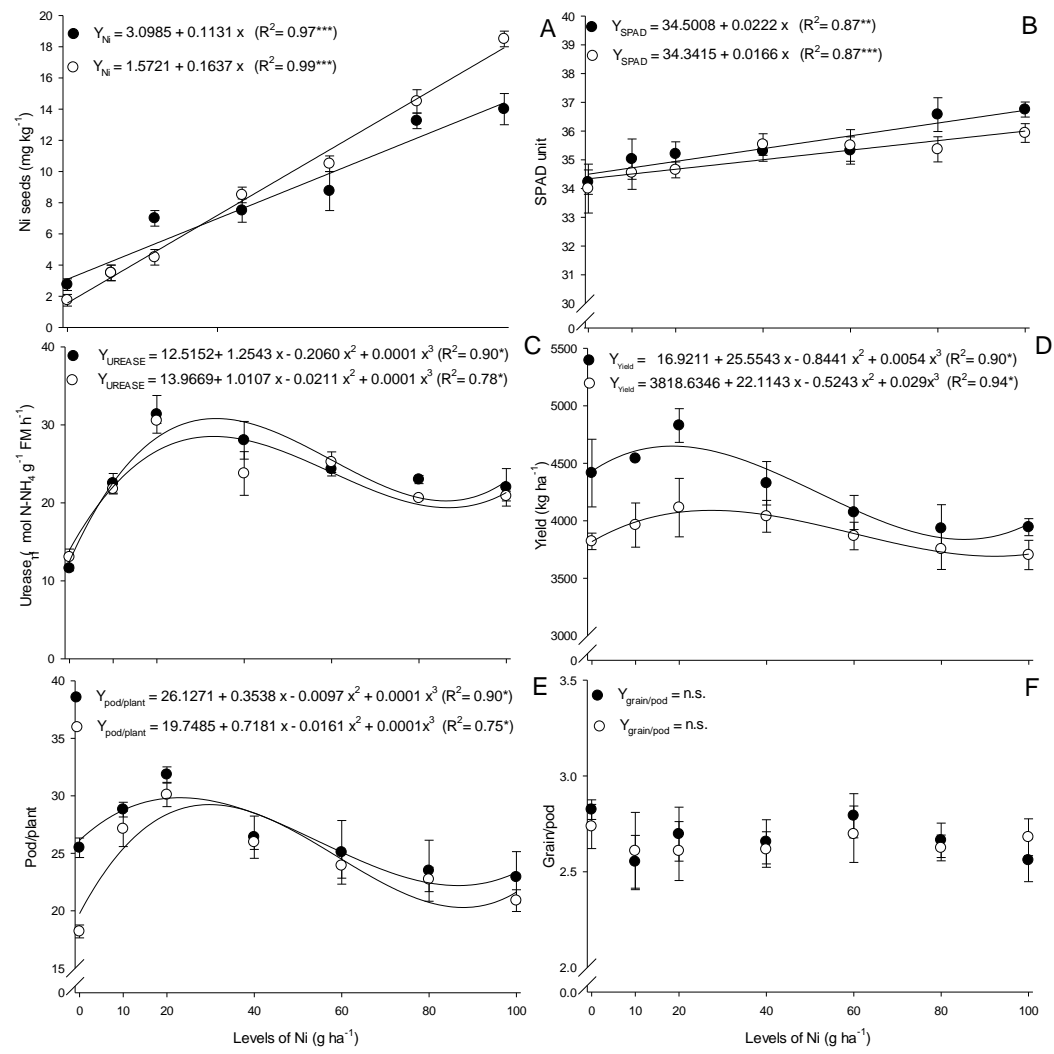

Fig 3. Nickel concentration in seeds $[A]$, SPAD unit $[B]$, urease activity $[C]$, yield $[D]$, number of pods per plant $[E]$, and number of seed per pod $[\mathrm{F}]$ in response to $\mathrm{Ni}$ application with or without pyroclostrobin. Open circles: $\mathrm{Ni}+$ pyraclostrobin; dark circles: $\mathrm{Ni}$ only. The error bars indicate the standard deviation of four replicates $(n=4)$. 

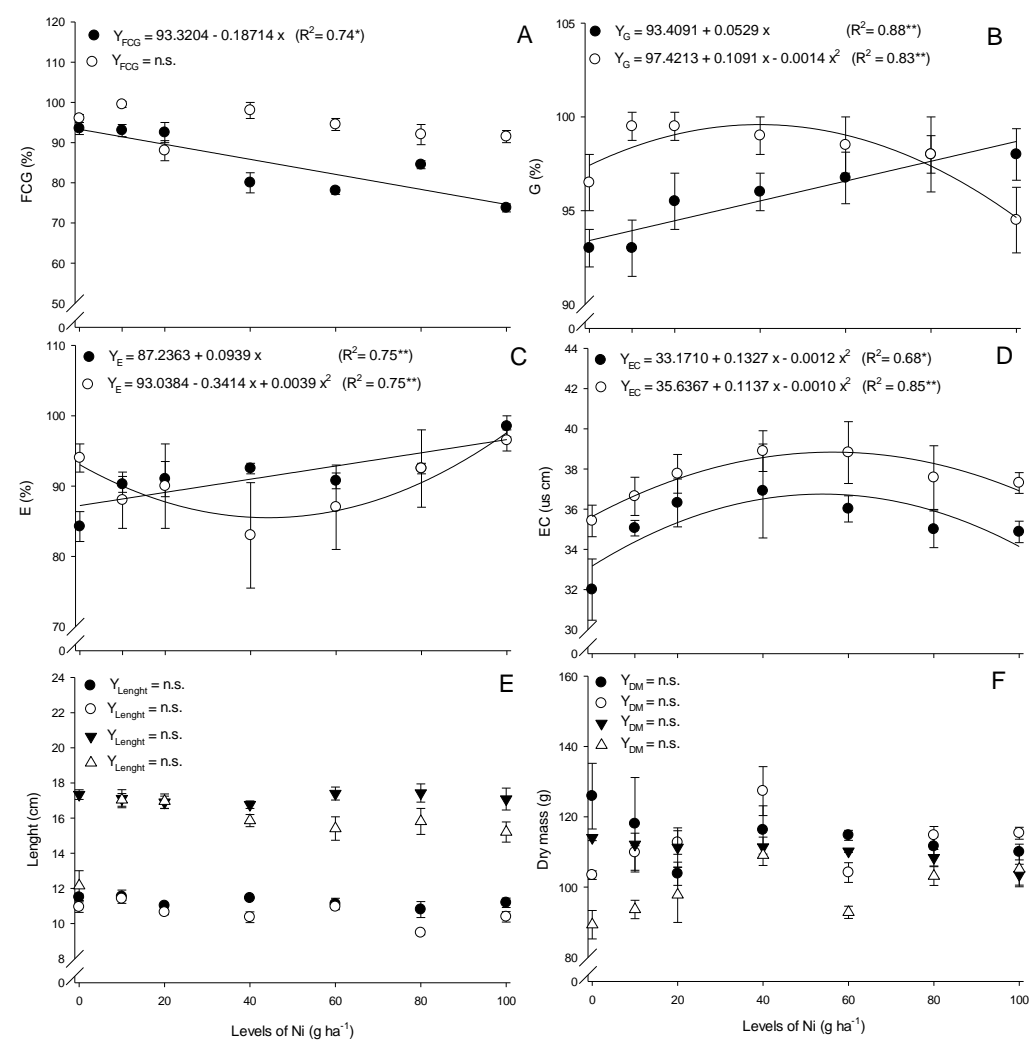

Fig 4. First count of germination (5 days) $(\mathrm{PCG})[\mathrm{A}]$, germination (8 days) $(\mathrm{G})[\mathrm{B}]$, emergence $(\mathrm{E})[\mathrm{C}]$, electrical conductivity (E) $[D]$, seedling length $[\mathrm{E}]$, and seedling dry weight $[\mathrm{F}]$ in response to $\mathrm{Ni}$ application with or without pyroclostrobin. Open circles: $\mathrm{Ni}+$ pyraclostrobin; dark circles: Ni only. The error bars indicate the standard deviation of four replicates $(n=4)$.
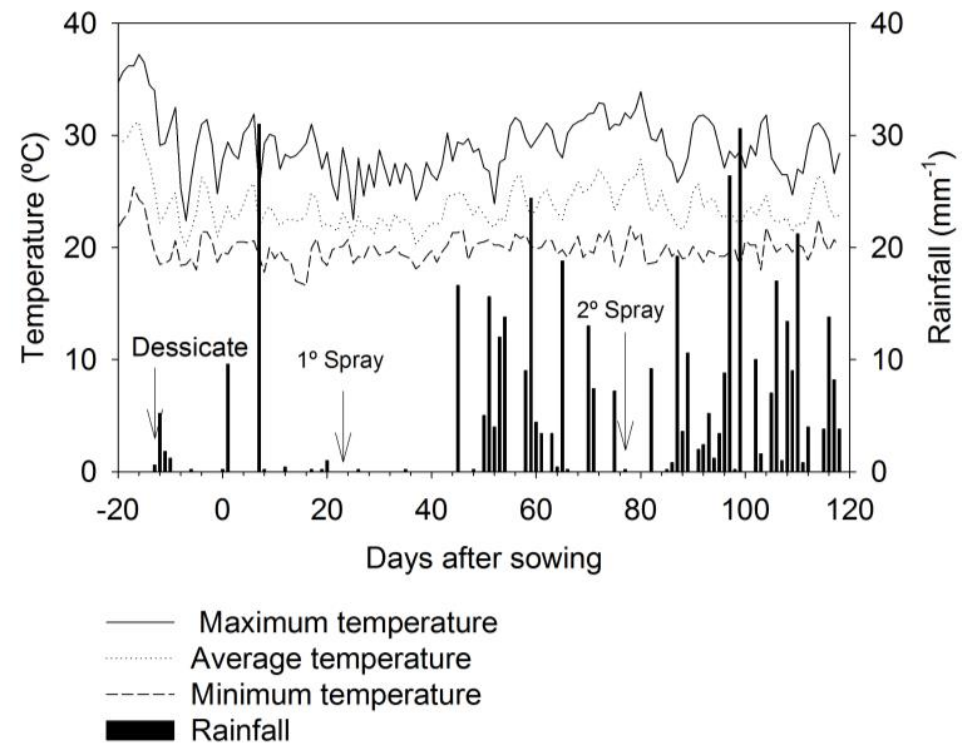

Fig 5. Rainfall and temperature average during experiment conduction at Chapadão do Sul, State of Mato Grosso do Sul, Brazil. 
The foliar zinc concentration (Fig. 2e), showed a similar response to those obtained for foliar iron concentration (Fig. 2c) showing a parabolic response in response to $\mathrm{Ni}$ application and an inverted parabolic response when $\mathrm{Ni}$ was combined with pyraclostrobin. The highest zinc concentration was obtained at $40 \mathrm{~g} \mathrm{ha}^{-1}$ of $\mathrm{Ni}$ in the absence of pyroclostrobin. In addition, in the absence of $\mathrm{Ni}$, pyraclostrobin application produced higher foliar zinc concentrations. Nickel also uses zinc transporters, members of the ZIP family, and there is greater Ni accumulation in zinc deficient plants (Nishida et al., 2015).

Foliar manganese concentration in soybean leaves showed a parabolic response to the to $\mathrm{Ni}$ application (Fig. 2d). The foliar manganese concentration increased up to $40 \mathrm{~g} \mathrm{ha}^{-1}$ of $\mathrm{Ni}$, decreasing with higher levels. Compared to $\mathrm{Cu}$ and $\mathrm{Fe}, \mathrm{Ni}$ combined with pyroclostrobin promoted higher foliar manganese concentrations. Nickel can compete with manganese for uptake, and White (2012) suggests that ZIP family transporters also carry manganese through the cells. The effects of $\mathrm{Ni}$ application on the mineral nutritional status of ryegrass plants have been described. Iron, zinc and manganese concentrations in shoots were inversely proportional to Ni concentrations (Khalid and Tinsley, 1980). The leaf zinc concentrations were negatively correlated with $\mathrm{Ni}$ concentrations in leaves (Table $1, \mathrm{r}=-0.86$ ), and seeds (Table $1, r=-0.79$ ), showing the antagonistic relationship between these two cations. Nickel does not use specific cation transporters such as YSL, ZIP/Nramp and nicotianamine synthase, thus it can compete with other divalent cations, especially copper, iron, manganese and zinc (Douchkov et al., 2005; Mizuno et al., 2005; Gendre et al., 2006).

In this study, the $\mathrm{Ni}$ concentration in leaves increased in response to $\mathrm{Ni}$ supply (Fig. 2f), corroborating with other studies the effect of $\mathrm{Ni}$ application in soybean plants (Queiroz, 2012; Rodak, 2014; Franco, 2015). According to Cataldo et al. (1978) during senescence soybean plants translocate about $70 \%$ of $\mathrm{Ni}$ to the seeds, confirming results obtained in this report where foliar $\mathrm{Ni}$ concentrations positively correlated with seed Ni concentrations (Table 1, r $=0.99)$. Similar results were also observed by Kutman et al. (2014) and Rodak (2014). The Ni concentration in seeds was higher when $\mathrm{Ni}$ application was combined with pyroclostrobin, demonstrating a possible synergistic effect of pyraclostrobin in the accumulation of $\mathrm{Ni}$ in soybean seeds (Fig. 3a).

\section{Chorophyll and urease activity}

The SPAD index was linearly proportional to foliar $\mathrm{Ni}$ application (Fig. 3b). This index estimates the amount of chlorophyll present in the leaves and showed a positive correlation with foliar nitrogen concentrations (Table $1, r=$ 0.83 ). The foliar nitrogen concentration was positively correlated with the $\mathrm{Ni}$ concentration in the leaves (Table $1, \mathrm{r}$ $=0.96$ ) and seeds (Table $1, r=0.98)$. Foliar Ni concentration also showed a positive correlation with the SPAD index (Table $1, r=0.92$ ) and urease activity (Table $1, r=0.81$ ).

Nickel is a cofactor of urease, playing an important role in nitrogen recycling in higher plants (Polacco et al., 2013; Fabiano et al., 2015). Our results show a correlation between $\mathrm{Ni}$ and the chlorophyll content and consequently on the SPAD index.

Urease activity increased up to $40 \mathrm{~g} \mathrm{ha}^{-1}$ of $\mathrm{Ni}$, showing the highest activity between levels 20 and $40 \mathrm{~g} \mathrm{ha}^{-1}$ of $\mathrm{Ni}$ application (Fig. 3c) followed by a decrease under the highest levels of Ni exposure. Similar results were observed by
Rodak (2014), showing that urease activity in soybean leaves was inhibited in presence of high concentrations of Ni. In this study, the urease enzyme activity correlated with the seed yield (Table $1, r=0.88$ ) and number of pods (Table $1, r=$ $0.84)$.

\section{Soybean yield and physiological quality of seeds}

The soybean yield (Fig. 3d) and the number of pods (Fig. 3e) increased in response to $\mathrm{Ni}$ application up to $20 \mathrm{~g} \mathrm{ha}^{-1}$ but were inhibited in the presence of pyroclostrobin. According to Moraes et al. (2010), under Brazilian environmental conditions, soybean yield increased approximately $300 \mathrm{~kg}$ ha ${ }^{1}$ when plants were sprayed with $50 \mathrm{~g} \mathrm{ha}^{-1}$ of $\mathrm{Ni}$. The increase in soybean yield by the foliar application of $\mathrm{Ni}$ can be attributed to the effect of $\mathrm{Ni}$ on reducing symptoms of fungal infection (Reis et al., 2014; Godoy et al., 2016; Langenbach et al., 2016).

Regarding the physiological quality of seeds, the first count of germination (PGC) decreased in response to $\mathrm{Ni}$ application though PGC was higher in the presence of pyroclostrobin (Fig. 4a). Conversely the percentage of germination (Fig. 4b) and emergence (Fig. 4c) increased linearly with foliar $\mathrm{Ni}$ supply in the absence of pyroclostrobin. The germination percentage showed a slight increase up to $40 \mathrm{~g} \mathrm{ha}^{-1}$ when $\mathrm{Ni}$ was combined with pyraclostrobin and emergence showed an inverted parabolic response when $\mathrm{Ni}$ and pyroclostrobin were combined. There is a lack of information regarding the effect of Ni fertilization on physiological quality of seeds. Brown et al. (1987) observed that the germination rates of barley seeds increased in plants previously enriched with $\mathrm{Ni}$. The electrical conductivity of seeds increased in response to levels of $\mathrm{Ni}$ up to 40 and $60 \mathrm{~g} \mathrm{ha}^{-1}$ of $\mathrm{Ni}$ regardless of pyraclostrobin status. However the treatments with fungicide showed higher values of electrical conductivity (Fig. 4c). These results suggest that the foliar Ni application combined with pyraclostrobin show an additive effect on seed deterioration, generating seeds with high membrane degradation.

There was no significant effect of $\mathrm{Ni}$ on seedling length and seedling dry weight. According to Pearson's correlation, shoot dry weight was positively correlates with root dry weight (Table 1, $\mathrm{r}=0.93$ ). Piccini and Malavolta (1992) studied the toxic effect of $\mathrm{Ni}$ in Phaseolus vulgaris plants and observed a reduction in root growth as well as considerable inhibitory effect on the morphogenesis and plant growth, and seed formation.

There are few studies evaluating the effect of foliar $\mathrm{Ni}$ application on the physiological quality of soybean seeds (Kutman et al, 2013a; Rodak, 2014). It is known that seed storage compounds have great influence on physiological seed quality. Therefore, further studies are needed in order to better understand the physiological roles of $\mathrm{Ni}$ on soybean seed germination.

\section{Materials and Methods}

\section{Plant materials}

The experiment was conducted using a no-tillage system on cultural remains of forage turnips. The desiccation of the area was performed 15 days before sowing, using $1440 \mathrm{~g}$ of i.a. $\mathrm{ha}^{-1}$ glyphosate $+30 \mathrm{~g}$ i.a. ha ${ }^{-1}$ carfentrazone-ethyl.

The soybean cultivar that was used was the Anta $82 \mathrm{RR}$, semi-determined growth habit, which shows an approximate cycle of 115 days. The seeds were pretreated with fipronil, thiophanate methyl, and pyraclostrobin at $5 \mathrm{~g}$ i.a., $45 \mathrm{~g}$ i.a. 
and $50 \mathrm{~g}$ i.a. per $100 \mathrm{~kg}$ of seed respectively. The seeding fertilization was based on $200 \mathrm{~kg} \mathrm{ha}^{-1}$ MAP 10-50-00. The inoculation was performed by direct spraying into the planting furrow, using $600 \mathrm{~mL} \mathrm{ha}{ }^{-1}$ of liquid inoculant containing Bradyrhizobium japonicum.

The sowing was carried out aiming for a stand of 340.000 plants ha ${ }^{-1}$. Each experimental plot consisted of six lines of 6 $\mathrm{m}$ each with $0.45 \mathrm{~m}$ between each line. The plants harvested for measurement came from the two central lines, excluding $0.5 \mathrm{~m}$ on both ends. The data of rainfall and average temperatures during the crop cycle are shown in Fig. 5.

During the plant development cycle, phytosanitary management was carried out twice. The first was done 25 days after sowing using: glyphosate (1.44 g i.a. ha $\left.{ }^{-1}\right)$, clorantraniliprole (10 g i.a. ha $\left.{ }^{-1}\right)$ and teflubenzuron (15 g i.a. $\left.\mathrm{ha}^{-1}\right)$. The second application was made 75 days after sowing using clorantraniliprole (10 g i.a. $\left.\mathrm{ha}^{-1}\right)$, teflubenzuron $(15 \mathrm{~g}$ i.a. $\left.\mathrm{ha}^{-1}\right)$ and acephate $\left(800 \mathrm{~g}\right.$ i.a. ha $\left.{ }^{-1}\right)$. For specific management of soybean rust along with pyraclostrobin, the plots were treated with trifloxystrobin $\left(60 \mathrm{~g}\right.$ i.a. $\left.\mathrm{ha}^{-1}\right)$ and prothioconazole $\left(70 \mathrm{~g}\right.$ i.a. $\left.\mathrm{ha}^{-1}\right)$ twice. The first treatement was during R1 and the second 20 days later.

\section{Characterization of the experimental area}

This study was conducted between November $1^{\text {st }}, 2014$ to February $27^{\text {th }}, 2015$ at the Campo Bom Experimental Farm, located in Chapadao do Sul, State of Mato Grosso do Sul, Brazil (Latitude 18 $18^{\circ} 6^{\prime} 24.38^{\prime \prime}$ South and Longitude $52^{\circ} 37^{\prime} 23.75^{\prime \prime}$ West), with an average altitude of $820 \mathrm{~m}$. The climate is classified as tropical humid with dry winters and rainy summers, with average temperatures ranging between 13 and $28{ }^{\circ} \mathrm{C}$ and an average annual rainfall of $1.850 \mathrm{~mm}$ (Cunha et al., 2013).

The soil of the area was classified as red latosol (LVd) very clayey, and corresponds to the Oxisol order (Soil Survey Staff, 1999). Soil analysis was performed according to the methodology described by Raij et al. (2001). The soil properties showed the following chemical characteristics: $\mathrm{pH}\left(\mathrm{CaCl}_{2}\right)$ 4.7; calcium 2.6 cmolc $\mathrm{dm}^{-3}$; magnesium 0.5 cmolc dm $\mathrm{dm}^{-3}$; aluminum $0.18 \mathrm{cmolc} \mathrm{dm}^{-3} ; \mathrm{H}^{+}+\mathrm{Al} 6.7 \mathrm{cmolc}$ $\mathrm{dm}^{-3}$; potassium $58 \mathrm{mmol} \mathrm{dm}^{-3}$; phosphorus (Melich) $6 \mathrm{mg}$ $\mathrm{dm}^{-3}$; sulfur $4.8 \mathrm{mg} \mathrm{dm}^{-3}$; boron $0.36 \mathrm{mg} \mathrm{dm}^{-3}$; copper $0.9 \mathrm{mg}$ $\mathrm{dm}^{-3}$; iron $49 \mathrm{mg} \mathrm{dm}^{-3}$; manganese $9.5 \mathrm{mg} \mathrm{dm}^{-3}$; zinc $2.7 \mathrm{mg}$ $\mathrm{dm}^{-3}$; organic matter $25 \mathrm{~g} \mathrm{dm}^{-3}$; nickel $0.1 \mathrm{mg} \mathrm{dm}^{-3}$; cation exchange capacity $9.9 \mathrm{cmolc} \mathrm{dm}^{-3}$. The physical properties of soil are: clay $610 \mathrm{~g} \mathrm{dm}^{-3}$; silt $50 \mathrm{~g} \mathrm{dm}^{-3}$; and sand $340 \mathrm{~g} \mathrm{dm}^{-3}$.

\section{Experimental design and treatments}

The study was conducted using a randomized plot experimental design; with seven different levels of $\mathrm{Ni}(0,10$, $20,40,60,80$ and $\left.100 \mathrm{~g} \mathrm{ha}^{-1}\right)$ using as nickel sulfate as the source (Sigma Aldrich) in presence or absence of fungicide (0 or $75 \mathrm{~g}$ i.a. ha ${ }^{-1}$ of pyraclostrobin) (Trademark Comet). The foliar application of treatments was performed during phenological stage R1 with with each treatment scheme performed in quadriplate, resulting in 56 individual plots.

\section{Mineral nutrition analysis}

For mineral nutrition analysis the third trefoil was collected from 20 plants per plot at 12 days post $\mathrm{Ni}$ application. The soybean plants were in the R2 phenological stage of development. The collected samples were dried and used to quantify leaf concentrations of macro and micronutrients.
The soybean seeds harvested during the R8 phenological stage were also analyzed.

The nitrogen concentration was determined by the semimicro Kjeldahl method after sulfuric digestion (Malavolta et al., 1997). For the quantification of other nutrients, a nitropercloric digestion was carried out (Johnson and Ulrich, 1959) and incineration in the case of boron (Alcarde, 1969). Nutrient determination was performed using atomic absorption spectrophotometry, except for phosphorus and sulfur, which were determined by colorimetric spectrophotometry.

\section{Chlorophyll Index}

During the R2 phenological stage of soybean development, indirect measurements of chlorophyll were made using a portable chlorophyll meter (SPAD 502 digital model) (MINOLTA). An average of 10 readings per trefoil was obtained under field conditions. The SPAD readings were obtained from 15 trefoils per plot.

\section{Urease activity (EC 3.5.1.5)}

The third trefoil was collected from the apex in order to measure the urease activity (EC 3.5.1.5.). The samples were collected during R2 phenological stage at 10 days post- $\mathrm{Ni}$ application. The samples were transported immediately to the laboratory for extraction and analysis of urease activity.

The urease activity was determined by the production of $\mathrm{N}$ $\mathrm{NH}_{4}$ according to McCullough (1967) and the extract was obtained according to the methodology described by Hogan et al. (1983). After collection, $0.2 \mathrm{~g}$ of leaf (fresh weight) was placed in $8 \mathrm{~mL}$ of sodium phosphate buffer containing urea at $\mathrm{pH} 7.4$ and was incubated at $30{ }^{\circ} \mathrm{C}$ with stirring for 3 hours. To a $0.5 \mathrm{~mL}$ aliquot of the extract $2.5 \mathrm{~mL}$ of reagent $\mathrm{I}$ : [phenol $\left(0.1 \mathrm{~mol} \mathrm{~L}^{-1}\right)$ and sodium nitroprusside (SNP) (170

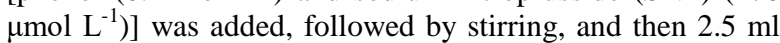
of reagent II: [sodium hydroxide $\left(0.125 \mathrm{~mol} \mathrm{~L}^{-1}\right)$, disodium phosphate $\left(0.15 \mathrm{~mol} \mathrm{~L}^{-1}\right)$ and sodium hypochlorite $\left.\left(3 \% \mathrm{Cl}_{2}\right)\right]$. The samples were then incubated at $37{ }^{\circ} \mathrm{C}$ for 35 minutes. The determination was performed in a spectrophotometer at

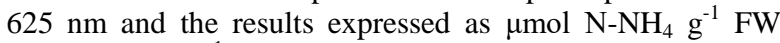
(fresh weight) $\mathrm{h}^{-1}$.

\section{Growth and yield assessment}

During the R8 phenological stage, the number of pods and seeds per pod were evaluated. The evaluation was conducted from five plants in the central area of each plot. During this same stage the average seed weight was determined from 100 seeds and an evaluation of soybean yield was also performed with standardized humidity at $13 \%$.

\section{Physiological quality of seeds}

In order to carry out the germination tests, seed samples from each plot were collect to perform the vigor tests soon after.

Germination test: 50 seeds were used per replicate and distributed between three sheets of "germitest" paper that were moistened with distilled water at 2.5 times the dry seed weight, and kept in a germinator at a constant temperature of $25{ }^{\circ} \mathrm{C}$. The first count of germination was performed five days and the final count was performed eight days after initiation, expressed as mean percentage of normal seedlings (Brasil, 2009). 
Seedling length test: there were four replicates of 20 seeds per treatment, packed in rolls previously moistened with distilled water 2.5 times dry seed weight, grouped, closed in plastic bags and placed in a germinator at a constant temperature of $25{ }^{\circ} \mathrm{C}$. The length of normal seedlings was measured five days after the initiation. The values were summed and divided by the number of measured normal seedlings.

Seedlings used for the evaluation of dry mass were obtained from the length test. For this, the samples were dried in a forced circulation stove at $80{ }^{\circ} \mathrm{C}$ for 24 hours, weighed and divided by the number of normal seedlings to give the mean mass per seedling.

Emergence test: 200 seeds per treatment in four replications of 50 were put in expanded polystyrene trays, kept in the greenhouse and irrigated twice a day, with daily assessments until the tenth day after sowing.

Electrical conductivity: 50 seeds per treatment were placed in plastic cups with $75 \mathrm{~mL}$ of deionized water and incubated at $25{ }^{\circ} \mathrm{C}$; electral conductivity was determined after 24 hours of incubation (Vieira and Krzyzanowsky, 1999).

\section{Statistical analysis}

The data was submitted to analysis of variance using the SAS statistical program. Using the $\mathrm{F}$ test significance level for the treatments ( $\mathrm{Ni}$ levels and pyraclostrobin), the data were submitted to linear and quadratic regression analysis using the GLM (general linear model). The correlations among dependent variables (leaf nutrients, urease activity, SPAD index, yield, and physiological quality parameters of seeds) were obtained by means of CORR procedure (Pearson correlation coefficient), using the SAS - System for Windows 6.11 (SAS Inst. 1996).

\section{Conclusion}

The foliar $\mathrm{Ni}$ application showed the most benefits on mineral nutrition status, urease activity and seed physiological quality under low $\mathrm{Ni}$ concentrations combined with pyraclostrobin. Nickel foliar application at higher concentrations combined with pyraclostrobin apparently enhances the $\mathrm{Ni}$ antagonistic effects on cationic micronutrients in soybean plants. There was no significant effect of the treatments on seedling length and seedling dry weight. Foliar application of Ni up to $20 \mathrm{~g} \mathrm{ha}^{-1}$ regardless of pyraclostrobin co-treatment was beneficial to soybean plants based on seed yield, mineral nutrition status and physiological quality of soybean seeds.

\section{Acknowledgments}

JPQB, and ARR thanks to CAPES and CNPq for fellowship and financial support.

\section{References}

Alcarde JCA (1969) A determinação do boro em plantas pelo método colorimétrico da curcumina. An Esc Super Agric Luiz de Queiroz. 26: 31-41.

Barsukova VS, Gamzikova OI (1999) Effects of nickel surplus on the element content in wheat varieties contrasting in $\mathrm{Ni}$ resistance. Agric Chem. 1: 80-85.

Brasil - Ministério da Agricultura, Pecuária e Abastecimento (2009). Regras para análise de sementes. 1st edn. Mapa/ACS, Brasília.
Brown PH, Welch RM, Cary EE (1987) Nickel: a micronutrient essential for higher plants. Plant Physiol. 85(3): 801-803.

Campbell WH (1999) Nitrate reductase structure, function and regulation: bridging the gap between biochemistry and physiology. Ann Rev Plant Biol. 50(1): 277-303.

Carrijo DR (2014) Efeitos fisiológicos provocados pelo fungicida fluxapiroxade, isolado e em mistura com a piraclostrobina, na cultura de soja. Master's Thesis. Escola Superior de Agricultura Luiz de Queiroz, Universidade de São Paulo, Piracicaba.

Cataldo DA, Garland TR, Wildung RE (1978) Nickel in plants. I. uptake kinetics using intact soybean seedlings. PlantPhysiol. 62: 5636-5665.

Ciurli S (2001) Electronic structure of the nickel ions in the active site of urease. Chemistry. 2001: 99-100.

Cunha FF, Magalhães FF, Castro MA (2013) Methods for estimating reference evapotranspiration for Chapadão do Sul MS. Eng Agric. 21(2): 159-172.

Dixon NE, Gazzola C, Blakeley RL, Zerner B (1975) Jack bean urease (EC 3.5.1.5) a metalloenzyme: simple biological role for nickel. J Am Chem Soc. 97(14): 4131-4133.

Douchkov D, Gryczka C, Stephan UW, Hell R, Bäumlein H (2005) Ectopic expression of nicotianamine synthase genes results in improved iron accumulation and increased nickel tolerance in transgenic tobacco. Plant Cell Environ. 28(3): 365374.

Eskew DL, Welch RM, Cary EE (1983) Nickel: an essential micronutrient for legumes and possibly all higher-plants. Science. 222: 621-623.

Eskew DL, Welch RM, Norvell WA (1984) Nickel in higher plants: further evidence for an essential role. Plant Physiol. 76(3): 691-693.

Fabiano CC, Tezotto T, Favarin JL, Polacco JC, Mazzafera P (2015) Essentiality of nickel in plants: a role in plant stresses. Front Plant Sci. 6(754): 1-4. DOI:10.3389/fpls.2015.00754

Fagan EB, Dourado Neto D, Vivian R, Franco RB, Yeda MP, Massignam LF, Oliveira RF, Martins KV (2010) Effect of pyraclostrobin application on the photosynthesis rate, respiration, nitrate reductase activity and productivity of soybean crop. Bragantia. 69(4): 771-777.

Franco GC (2015) Tratamento de sementes de soja com níquel para o aumento da fixação biológica e atividade da urease. Master's Thesis. Centro de Energia Nuclear na Agricultura da Universidade de São Paulo Universidade de São Paulo, 67p.

Gendre D, Czernic P, Conéjéro G, Pianelli K, Briat JF, Lebrun M, Mari S (2007) TcYSL3, a member of the YSL gene family from the hyperaccumulator Thlaspi caerulescens, encodes a nicotianamine- Ni/Fe transporter. The Plant J. 49: 1-15.

Ghasemi R, Ghaderian SM, Krämer U (2009) Interference of nickel with copper and iron homeostasis contributes to metal toxicity symptoms in the nickel hyperaccumulator plant Alyssum inflatum. New Phytol. 184(3): 566-580.

Ghasemi R, Ghaderian SM, Ebrazeh S (2015) Nickel stimulates copper uptake by nickel-hyperaccumulator plants in the genus Alyssum. Aust J Bot. 63(2): 56-64.

Godoy CV, Seixas CDS, Soares RM, Marcelino-Guimarães FC, Meyer MC, Costamilan LM (2016) Asian soybean rust in Brazil: past, present, and future. Pesq Agrop Bras. 51(5): 407421.

Hogan ME, Swift IE, Done J (1983) Urease assay and ammonia release from leaf tissues. Phytochemistry. 22(3): 663-667.

Johnson CM, Ulrich A (1959) Analytical methods for use in plants analyses. Los Angeles, University of California 766: 3233.

Kabata-Pendias A, Pendias H (2011) Trace Elements in Soil and Plants. 4th edn. CRC Press, 505p.

Kämpf N, Marques JJ, Curi N (2012) Mineralogia de solos brasileiros. In: Ker JC, Curi N, Schaefer CEGR, Torrado-Vidal P (eds.) Pedologia. Sociedade Brasileira de Ciência do Solo, Viçosa. 343p. 
Kappes C, Golo AL, de Carvalho, MAC (2008) Doses and periods of boron foliar application on agronomic characteristics and quality of soybean seeds. Sci Agrar. 9(3): 291-297.

Kevresan S, Petrovic N, Popovic M, Kandrac J. (1998) Effect of heavy metals on nitrate and protein metabolism in sugar beet. Biol Plant. 41: 235-240.

Khalid BY, Tinsley J (1980) Some effects of nickel toxicity on rye grass. Plant Soil. 55: 139-144.

Korner LE, Moller L, Jensén MP (1987) Effects of $\mathrm{Ca}^{2+}$ and other divalent cations on uptake of $\mathrm{Ni}^{2+}$ by excised barley roots. Physiol Plant. 71: 49-54.

Küpper H, Andresen E (2016) Mechanisms of metal toxicity in plants. Metallomics 8: 269-285.

Kutman BY, Kutman UB, Cakmak I (2013a) Nickel-enriched seed and externally supplied nickel improve growth and alleviate foliar urea damage in soybean. Plant Soil. 363: 61-75.

Kutman BY, Kutman UB, Cakmak I (2013b) Foliar nickel application alleviates detrimental effects of glyphosate drift on yield and seed quality of wheat. J Agr Food Chem. 61(35): 8364-8372.

Kutman BY, Kutman UB, Cakmak I (2014) Effects of seed nickel reserves or externally supplied nickel on the growth, nitrogen metabolites and nitrogen use efficiency of urea- or nitrate-fed soybean. Plant Soil. 376: 261-276.

Langenbach C, Campe R, Beyer S, Mueller AN, Conrath U (2016) Fighting asian soybean rust. Front Plant Sci. 7: 797. DOI: $10.3389 /$ fpls.2016.00797

Lavres J, Franco GC, Câmara GMS (2016) Soybean seed treatment with nickel improves biological nitrogen fixation and urease activity. Front Environ Sci. 4: 37. DOI: 10.3389/fenvs.2016.00037

Lima JD, Moraes WDS, Silva MG, Helena S (2012) Physiological responses in the banana plantlets treated with strobilurins. Semina Ciê Agr. 33: 77-86.

Malavolta E, Vitti GC, Oliveira SA (1997) Avaliação do estado nutricional de plantas: princípios e aplicações. 2nd edn. Potafós, Piracicaba 319p.

Malavolta E, Moraes MF (2007) Nickel - from toxic to essential nutrient. Better Crops. 91(3): 26-27.

McCullough H (1967) The determination of ammonia in whole blood by a direct colorimetric method. Clin Chim Acta. 17(2): 297-304.

Mizuno T, Usui K, Horie K, Nosaka S, Mizuno N, Obata H (2005) Cloning of three ZIP/Nramp transporter genes from a $\mathrm{Ni}$ hyperaccumulator plant Thlaspi japonicum and their $\mathrm{Ni}^{2+}$ transport abilities. Plant Physiol Biochem. 43(8): 793-801.

Moraes MF, Abreu Junior CH, Lavres Junior J (2010) Micronutrientes. In: Prochnow LI, Casarin V, Stipp SR (eds.). Boas práticas para uso eficiente de fertilizantes. International Plant Nutrition Institute, Piracicaba. 2: 205-278.

Nishida S, Aisu A, Mizuno T (2012) Induction of IRT1 by the nickel-induced iron-deficient response in Arabidopsis. Plant Signal Behav. 7: 329-331.

Nishida S, Kato A, Tsuzuki C, Yoshida J, Mizuno T (2015) Induction of nickel accumulation in response to zinc deficiency in Arabidopsis thaliana. Int J Mol Sci. 16(5): 9420-9430.

Ojeda-Barrios DL, Sánchez-Chávez E, Sida-Arreola JP, ValdezCepeda R, Balandran-Valladares M (2016) The impact of foliar nickel fertilization on urease activity in pecan trees. $J$ Soil Sci Plant Nutr. 16(1): 237-247.

Piccini DF, Malavolta E (1992) Effect of nickel on two common bean cultivars. J Plant Nutr. 15: 2343-2350.

Polacco JC, Mazzafera P, Tezotto T (2013) Opinion-nickel and urease in plants: still many knowledge gaps. Plant Sci. 199: 7990.

Prosser IA, Purves JV, Saker LR, Clarkson DT (2001) Rapid disruption of nitrogen metabolism and nitrate transport in spinach plants deprived of sulphate. J Exp Bot. 52: 113-121.
Queiroz CS (2012) Níquel, outros micronutrientes e silício e a ferrugem asiática (Phakopsora pachyrhizi) na cultura da soja (Glycine Max). Master's Thesis. Universidade Federal de Goiás, Escola de Agronomia, Goiânia, 2012.

Rahman H, Sabreen S, Alam S, Kawai S (2005) Effects of nickel on growth and composition of metal micronutrients in barley plants grown in nutrient solution. J Plant Nutr. 28(3): 393-404.

Raij BV, Andrade JC, Cantarella H, Quaggio JA (2001) Análise química para avaliação da fertilidade de solos tropicais. Instituto Agronômico, Campinas. 285 p.

Reis AR, Rodak BW, Putti FF, Moraes MF (2014) Papel fisiológico do níquel: essencialidade e toxidez em plantas. Inform Agron. 147: 10-24.

Rodak BW (2014) Níquel em solos e na cultura de soja. Master's Dissertation Thesis. Universidade Federal do Paraná, Curitiba.

Rodrigues MAT (2009) Avaliação do efeito fisiológico do uso de fungicidas na cultura de soja. PhD Thesis. Escola Superior de Agricultura "Luiz de Queiroz", Universidade de São Paulo, Piracicaba.

Sá ME (1994) Importância da adubação na qualidade de sementes. In: Sá ME, Buzetti S (eds.) Importância da adubação na qualidade dos produtos agrícolas. Ícone, São Paulo. 65-98, 1994.

SAS Institute. SAS/STAT (1996) 'User's guide, version 6.11.' 4th ed SAS Institute Inc., Cary

Seregin IV, Kozhevnikova AD (2006) Physiological role of nickel and its toxic effects on higher plants. Russ J Plant Physiol. 53(2): 257-277.

Soil Survey Staff (1999) Soil taxonomy: a basic system of soil classification for making and interpreting soil surveys, 2nd edn. Natural Resources Conservation Service. United States: Department of Agriculture. 1999.

Tan XW, Ikeda H, Oda M (2000) Effects of nickel concentration in the nutrient solution on the nitrogen assimilation and growth of tomato seedlings in hydroponic culture supplied with urea or nitrate as the sole nitrogen source. Sci Hortic-Amsterdam. 84(3): 265-273.

Thomas SG, Bilsborrow PE, Hocking TJ, Bennet J (2000) Effect of sulphur deficiency on the growth and metabolism of sugar beet (Beta vulgaris cv Druid). J Sci Food Agric. 80(14): $2057-$ 2062.

Vieira RD, Krzyzanowski FC (1999). Teste de condutividade elétrica. In: Krzyzanowski FC, Vieira RD, França Neto JB (eds.). Vigor de sementes: conceitos e testes. Londrina: ABRATES, Londrina. 1999. cap. 4:1-26

Walker CD, Graham RD, Madison JT, Cary EE, Welch RM (1985) Effects of Ni deficiency on some nitrogen metabolites in cowpea (Vigna unguiculata L. Walp.). Plant Physiol. 79: 474-479.

White PJ (2012) Long-distance transport in the xylem and phloem. In: Marschner P (eds.). Marschner's Mineral Nutrition of Higher Plants, 3rd edn. Academic Press, London. 49-70. Marschner's Mineral Nutrition of Higher Plants. p. 49-70.

Witte CP (2011) Urea metabolism in plants. Plant Sci. 180: 431 438.

Zonia LE, Stebbins NE, Polacco JC (1995) Essential role of urease in germination of nitrogen-limited Arabidopsis thaliana seeds. Plant Physiol. 107: 1097-1103. 